\title{
Winter Diet of an Eurasian Eagle Owl Bubo bubo Near the Yedikır Dam, Amasya (Turkey)
}

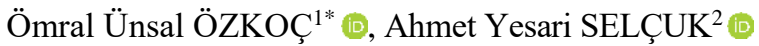 \\ ${ }^{1}$ Ondokuz Mayıs University, Graduate School of Science, Department of Biology, Samsun, TURKEY \\ ${ }^{2}$ Erciyes University, Faculty of Agriculture, Department of Agricultural Biotechnology, Kayseri, \\ TURKEY \\ *Corresponding Author: omral.ozkoc@yahoo.com.tr
}

Received Date: 07.10 .2020

Accepted Date: 14.04.2021
Abstract
Aim of study: The aim of this study was to contribute to the data on the diet of Eurasian Eagle Owl (Bubo bubo) in Turkey.
Area of study: This study was conducted near the Yedikur Dam (Amasya)
Material and methods: A total of 12 pellets of the Eurasian Eagle Owl collected in Yedikır Dam was analyzed. The remains of the skull and lower jaw were used for the identification of mammals.
Main results: 60 preys were identified to belong to 6 different taxa (5 Rodents and 1 Passerine). The main prey was Mus spp. (35.0\%). Only one bird remain was recorded from pellets.
Highlights: Pellet analyses were the first step for understanding the diet of B. bubo. Considering, $B$. bubo is an opportunistic predator and can consume medium-sized mammals and large-sized birds. Hence, a diet study supported with remains that are directly collected from the nest or perching site and their surroundings will reveal more objectively prey preferences for this apex predator.
Keywords: Feeding Biology, Pellet Analyses, Rodentia, Northern Anatolia

\section{Amasya, Yedikır Barajı'nda Bir Puhu (Bubo bubo)'nun Kış \\ Diyeti}

$\ddot{O} \mathbf{z}$

Çalışmanın amacı: Bu çalışmanın temel amacı, Puhunun (Bubo bubo) Türkiye'deki diyetine ilişkin verilere katkıda bulunmaktır.

Çalışma alanı: Bu çalışma Amasya Yedikır Barajı'nda gerçekleştirilmişstir.

Materyal ve yöntem: Yedikır Barajı'nda toplanan Puhuya ait toplam 12 pelet incelendi. Kafatası kalıntıları ve alt çene kemikleri mikro memelilerin tanımlanmasında kullanılmıştır.

Temel sonuçlar: 6 farklı taksona (5 Rodent ve 1 Passerin) ait 60 av tespit edilmiştir. Ana av, Mus spp. (\% 35,00) olarak belirlenmiştir. Peletlerden yalnızca bir kuşa ait kalıntı elde edilmiştir.

Araştırma vurgulart: Pelet analizleri, Puhunun diyetini anlamanın ilk basamağıydı. Öte yandan, B. bubo firsatçı bir avcıdır ve orta büyüklükteki memelileri ve büyük boy kuşları da avlayabilir. Bu nedenle, doğrudan yuva veya tüneme alanı ve çevresinden toplanan kalıntılarla desteklenen bir diyet çalışması, bu süper yırtıcı için daha objektif av tercihlerini ortaya çıkaracaktır.

Anahtar Kelimeler: Beslenme Biyolojisi, Pelet Analizi, Rodentia, Kuzey Anadolu 


\section{Introduction}

Eurasian Eagle Owl (Bubo bubo) is a widespread mainly nocturnal and crepuscular (Mikkola, 1983) member of the Strigidae family in the Palearctic Region. It exists in an extremely large area with a horizontal distribution from Europe and Scandinavia in the west to central Siberia and Japan in the east. In the south, it is distributed from the Mediterranean Region to Iraq, Iran, Afghanistan, Pakistan, India, Tibet, China, and Korea (König \& Weick, 2008). B. bubo is distributed in a large part of the country. Despite this wide area, it has a very sparse distribution (Kirwan et al., 2010; Boyla et al., 2019). This apex predator has the potential to prey on all kinds of vertebrate groups including a large variety of mammals from the smallest insectivore to the medium-sized carnivore mammals (up to the size of Red Fox Vulpes vulpes; Obuch \& Bangjord, 2016), and a wide variety of invertebrates (Penteriani \& del Mar Delgado, 2019). It was also reported that B. bubo feeds on carcasses (Serrano, 2000; Díaz-Ruiz et al., 2010; Milchev \& Spassov, 2017). B. bubo is a "sit- and waithunter" (Cramp \& Simmons, 1985; Eriksen \& Wabakken, 2018) that regurgitates some parts of its prey as pellets at the perching and nesting sites (Guillaud et al., 2018). Pellets contain some indigestible remains such as bones, furs, feathers, invertebrate parts with chitin, fish scales and etc. (Taylor, 1994; Lynch, 2007; Yalden, 2009). As a common method to investigate the diet of owls, pellet analysis is advantageous as an easy and costefficient technique.

Many of the diet studies of $B$. bubo have been published all across its distribution area (Penteriani \& del Mar Delgado, 2019). Number of the studies investigating the diet of B. bubo in Turkey are limited (Morgan, 1983; Obuch, 1994; Obuch, 2001; De Cupere et al., 2009; Seçkin et al., 2012; Kaya \& Coşkun, 2014). Here, we present the basic data in the study area, to contribute to the knowledge gap on the diet of B. bubo in Turkey.

\section{Material and Methods}

The pellets of $B$. bubo were collected in Yedikır Dam $\left(40^{\circ} 46^{\prime} \mathrm{N}, 35^{\circ} 33^{\prime} \mathrm{E}\right)$, located within the borders of Amasya province, in northern Anatolia (Figure 1). The dam covers 593 ha of area and was designated a Wildlife Development Area and a Bird Sanctuary with an alternative name of "Yedikugular Bird Paradise" in 1989 (Magnin \&Yarar, 1997). The dam lake is mostly surrounded by dryland agricultural fields and pine tree plantations are dominant in the northeast part of the dam (Eken et al., 2006). Riparian vegetation is also visible near the plantation (Anonymus, 2012).

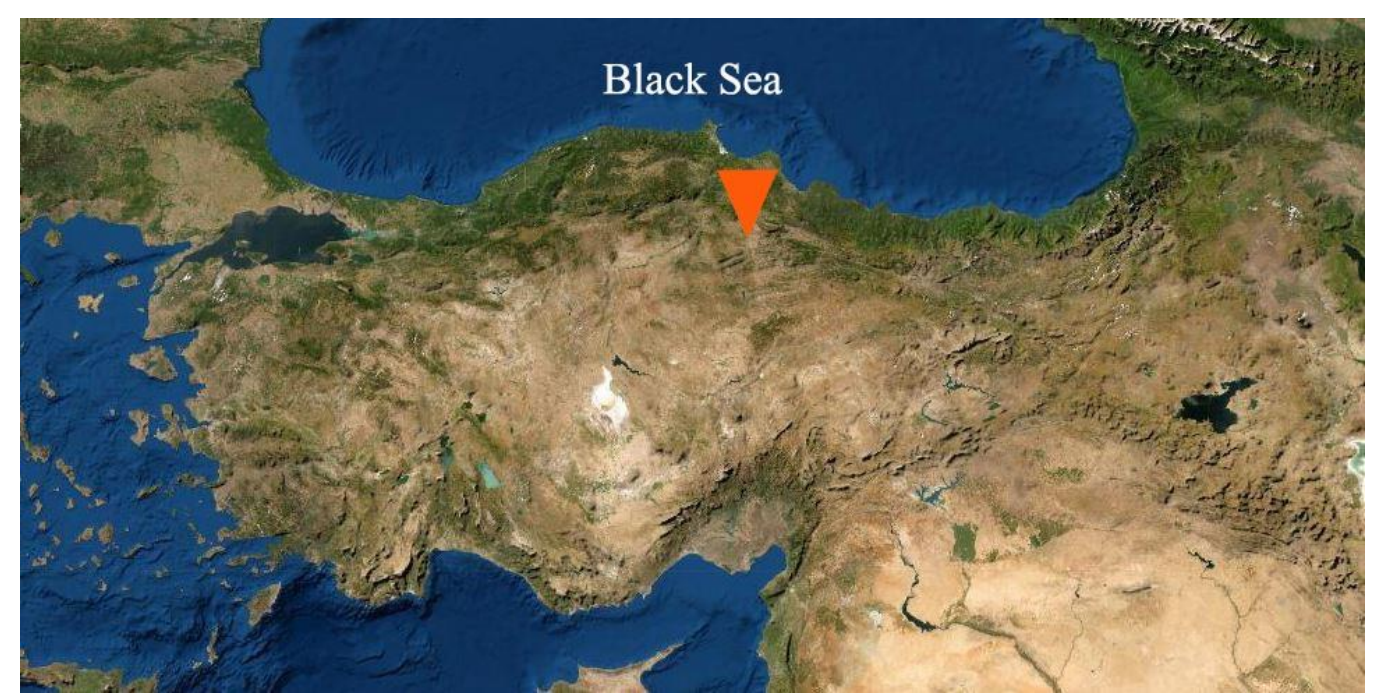

Figure 1. The location of study area

All pellets were collected under the riparian vegetation formed by sparse Salix alba, Salix excelsa and Tamarix tetrandra communities on 10th of January 2020. 
Before the examination, the width and length of pellets were measured at the centimeter level and the weight of the pellets was determined with a digital scale $( \pm 0.01 \mathrm{~g})$. The pellets were dehydrated by allowing them to dry at room temperature before weighing. Thereafter, the dissecting of the pellets was performed according to Yalden (2009). Each pellet was examined one after another to avoid the mistake of prey per pellet. Pellets were placed in water-filled beakers and beakers were kept in a $60^{\circ} \mathrm{C}$ water bath for 10 minutes to easily separate the fur from bones. The identification of small mammals was performed according to Krystufek \& Vohralik
(2005, 2009). Skull and lower jaw remains were used for the identification of micromammals. Only one remain of a bird was found in pellets. This was a keel bone, and couldn't be used for identification at the species level.

\section{Results}

A total of 12 pellets were collected in the study area (Figure 1). The mean diameter of the pellets was $3.61 \pm 0.58 \mathrm{~cm}(\mathrm{n}=11$; range: $2.87-4.88)$. The mean length of pellets was $8.27 \pm 1.63 \mathrm{~cm}(\mathrm{n}=11$; range: $6.11-10.81)$. The mean weight of pellets was $13.89 \pm 5.31$ $(n=12$, range: 8.92 - 26.49).

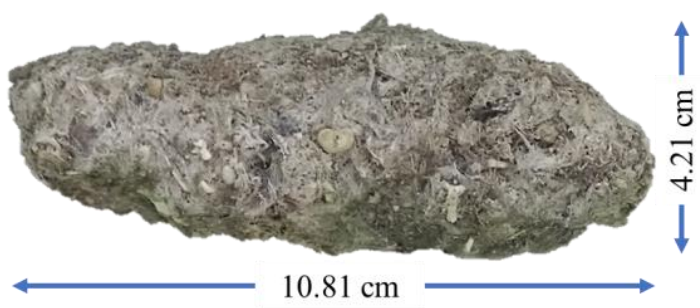

Figure 2. One sample of B. bubo's pellets in this study

60 preys distributed among 6 different taxa (5 small mammals and 1 bird) were identified in the collected pellets (Figure 2.). The prey rate per pellet was $5.0 \pm 3.0$ (range: $2-10$ ). A significant portion of the diet content consisted of small mammals $(\mathrm{F}=97.86 \%$; $\mathrm{B}$ $=98.33 \%$ ). All small mammals belong to the order Rodentia. Mus spp. $(\mathrm{F}=35.00 \%)$ were the most common prey in the diet followed by Tristram's Jird Meriones tristrami $(\mathrm{F}=23.33 \%)$ (Table 1).

Table 1. Diet content of Eurasian Eagle Owl, the minimum number of individuals (MNI), and frequency (F\%: frequency by the total prey number)

\begin{tabular}{lcc}
\hline Prey & MNI & F\% \\
\hline Microtus sp. & 4 & 6.6 \\
\hline Cricetulus migratorius & 10 & 16.6 \\
\hline Mesocricetus brandti & 10 & 16.6 \\
\hline Meriones tristrami & 14 & 23.3 \\
\hline Mus sp. & 21 & 35.0 \\
\hline Total of mammals & 59 & 98.3 \\
\hline Birds (unidentified) & 1 & 1.6 \\
\hline Total prey & 60 & 100 \\
\hline
\end{tabular}

\section{Discussion and Conclusions}

The pellets of $B$. bubo are quite large and that can reach up to size of $15 \mathrm{~cm}$ in length and $4 \mathrm{~cm}$ in diameter (Brown et al., 2003). Our samples also fit these measurements.

Being an opportunistic predator, the prey preferences of $B$. bubo vary widely. The list of all prey reported so far has been compiled in a monograph by Penteriani \& del Mar Delgado (2019). Our findings from the study area are consistent with the list.

Numerous studies from Turkey (Morgan, 1983; Obuch, 1994; Obuch, 2001; Obuch 2014; Seçkin et al., 2012; Kaya \& Coşkun, 2014) and other regions (Obuch \& Bangjord, 2016) show that the small mammals are an important part of B. bubo's diet. Seçkin et al. (2012) showed that the most abundant prey preference was Macedonian Mouse Mus macedonicus $(\mathrm{F}=33.65 \%)$ in their study conducted in Central Anatolia. Our findings were similar to the study of Seçkin et al. (2012) and the most common preys were Mus spp. $(\mathrm{F}=35.00 \%)$ in the present study. Typical mice Mus sp. were numerous preys also in the studies of Serrano (1998) and Milchev \& 
Georgiev (2019). Apart from small mammals, birds may be the most common preys, and these confirm that $B$. bubo is an opportunistic predator (Willgohs, 1974; Obuch \& Bangjord, 2016). In this study, only one keel bone belonging to a bird the size of a Sylvia warbler was identified among 60 preys. Dietary content may vary on the prey abundance or the season (Holt et al., 2020). Besides, mammals up to the size of the Red Fox Vulpes vulpes and large-sized birds are also included in the diet of B. bubo. Since this type of larger-sized prey cannot be swallowed as a whole (Lloveras et al., 2009), pellet samples regarding such a preference are insufficient in dietary studies. A diet study focusing on the materials directly collected from the nest and its surroundings would reveal the prey preferences of species more objectively, considering it is a powerful and opportunistic predator. An osteoarchaeological study using the bone remains collected from the breeding and roosting areas of the species in southwestern Turkey revealed more detailed findings. However, since the study was based not on pellet analysis, but identification of bone remains (De Cupere et al., 2009). Habitat, the location of the study area, the variety of the preys, and the number of individuals hunted by owls made the difference between the two studies. Therefore, it is not possible to compare the results.

In this study, B. bubo was reported from the study area for the first time through pellet analysis. No direct observation record of the species has been reported from the Yedikır Dam. In case of a regular perch to be found in the study site, a larger sample of pellets and other remains should be collected and analyzed in order to better understand the prey preferences of the species in the area.

\section{Acknowledgement}

We would like to thank Zehra Torun for her support in the field work.

\section{Ethics Committee Approval}

Ethical committee permit is not required for the present study.

\section{Peer-review}

Externally peer-reviewed.

\section{Author Contributions}

Conceptualization: Ö.Ü.Ö., $\quad$ A.Y.S.; Investigation: Ö.Ü.Ö., A.Y.S.; Material and Methodology: Ö.Ü.Ö., A.Y.S.; Supervision: Ö.Ü.Ö., A.Y.S.; Visualization: Ö.Ü.Ö., A.Y.S.; Writing-Original Draft: Ö.Ü.Ö., A.Y.S.; Writing-review \& Editing: Ö.Ü.Ö., A.Y.S.; Other: All authors have read and agreed to the published version of manuscript.

\section{Conflict of Interest}

The authors have no conflicts of interest to declare.

\section{Funding}

The authors declared that this study has received no financial support.

\section{References}

Anonymus, (2012). Yedikır Barajı sulak alan alt havzası biyolojik çeşitlilik araştırma alt projesi gelişme raporu. T.C. Orman ve Su İşleri Bakanlığı Orman ve Su İşleri XI. Bölge Müdürlüğü Amasya Şube Müdürlüğü.

Boyla, K. A., Sinav, L. \& Dizdaroğlu, D. E. (2019). Türkiye üreyen kuş atlast. WWFTürkiye, Doğal Hayatı Koruma Vakfi, İstanbul.

Brown, R., Ferguson, J., Lawrence, M. \& Lees, D. (2003). Tracks and signs of the birds of Britain and Europe: an identification guide (2nd edition). Christopher Helm, London.

Cramp, S. \& Simmons, K. E. L. (eds) (1985). Handbook of the birds of Europe, the Middle East and north Africa: the birds of the Western Palearctic. - Oxford Univ. Press.

De Cupere, B., Thys, S., Van Neer, W., Ervynck, A., Corremans, M. \& Waelkens, M. (2009). Eagle owl (Bubo bubo) pellets from Roman Sagalassos (SW Turkey): distinguishing the prey remains from nest and roost sites. International Journal of Osteoarchaeology, 19(1), 1-22.

Díaz-Ruiz, F., Buenestado, F., Fernández-deSimón, J. \& Ferreras, P. (2010). First record of rabbit carrion consumption by Eurasian Eagleowl (Bubo bubo) on the Iberian Peninsula. Journal Raptor Research, 44, 78-79.

Eken, G., Bozdoğan, M., İsfendiyaroğlu, S., Kılıç, D. T. \& Lise, Y., (Ed.). (2006). Türkiye'nin önemli doğa alanları. Ankara: Doğa Derneği.

Eriksen, A. \& Wabakken, P. (2018). Activity patterns at the Arctic Circle: nocturnal eagle owls and interspecific interactions during continuous midsummer daylight. Journal of Avian Biology, 49(7). 
Guillaud, E., Lebreton, L. \& Béarez, P. (2018). Taphonomic signature of Eurasian eagle owl (Bubo bubo) on fish remains. Folia Zoologica, 67(3-4), 143-153.

Holt, D. W., Berkley, R., Deppe, C., Enríquez, P. L., Petersen, J. L., Salazar, J. L. R., Segars, K. P., Wood, K. L. \& Marks, J. S. (2020). Eurasian Eagle-Owl (Bubo bubo), version 1.0. In Birds of the World (J. del Hoyo, A. Elliott, J. Sargatal, D. A. Christie, and E. de Juana, Editors). Cornell Lab of Ornithology, Ithaca, NY, USA.

Kaya, A. \& Coşkun, Y. (2014). Nevşehir'de baykuş peletlerindeki memeli hayvan kalıntılarının dağılımı. Nevşehir Bilim ve Teknoloji Dergisi, 3(1), 39-44.

Kirwan, G., Demirci, B., Welch, H., Boyla, K., Özen, M., Castell, P. \& Marlow, T. (2010). The birds of Turkey. Bloomsbury Publishing.

König, C. \& Weick, F. (2008). Owls of the world. London: Christopher Helm.

Kryštufek, B. \& Vohralik V. (2005). Mammals of Turkey and Cyprus. Order Rodentia I (Introduction, Checklist, Rodentia). Koper: Knjiznica Annales Majora.

Kryštufek, B. \& Vohralik V. (2009). Mammals of Turkey and Cyprus. Order Rodentia II (Introduction, Checklist, Rodentia). Koper: Knjiznica Annales Majora.

Lloveras, L., Moreno-García, M. \& Nadal, J. (2009). The eagle owl (Bubo bubo) as a leporid remains accumulator: taphonomic analysis of modern rabbit remains recovered from nests of this predator. International Journal of Osteoarchaeology, 19(5), 573-592.

Lynch, W. (2007). Owls of the United States and Canada. A complete guide to their biology and behavior. Baltimore: The Johns Hopkins University Press.

Magnin, G., \& Yarar, M. (1997). Important bird areas in Turkey. İstanbul: Doğal Hayatí Koruma Derneği.

Mikkola, H. (1983). Owls of Europe. Calton, U.K.: T. \& A. D Poyser.

Milchev, B. \& Spassov, N. (2017). First evidence for carrion-feeding of Eurasian Eagle-owl (Bubo bubo) in Bulgaria. Ornis Hungarica, 25(1), 58-69.

Morgan, D. (1983). An analysis of some Eagle Owl pellets from Turkey. Sandgrouse, 5, 105106.

Milchev, B. \& Georgiev, V. (2019). Food spectrum and predominant prey in the diet of the Eagle owl Bubo bubo population in southeastern Bulgaria. Forestry Ideas, 25, 5669.
Obuch, J. (1994). On the food of the eagle owl (Bubo bubo) and tawny owl (Strix aluco) in the eastern part of Turkey. Tichodroma 7, 7-16.

Obuch, J. (2001). Dormice in the diet of owls in the Middle East. Trakya University Journal of Scientific Research Series B, 2(2), 145-150.

Obuch, J. (2014). Spatial diversity in the diet of the Eurasian eagle owl Bubo bubo in Iran. Podoces, 9(1), 7-21.

Obuch, J. \& Bangjord, G. (2016). The Eurasian eagle-owl (Bubo bubo) diet in the Trøndelag region (Central Norway). Raptor Journal, 10(1), 51-64.

Penteriani, V. \& del Mar Delgado, M. (2019). The eagle owl. Bloomsbury Publishing.

Seçkin, S., Kaya, A. \& Coşkun, Y. (2012). Başaklı Köyü (Diyarbakır-Bismil) civarında yaşayan puhu (Bubo bubo)'ların peletlerindeki küçük memelilerin dağılımı. CÜ Fen Fakültesi Fen Bilimleri Dergisi, 33(1).

Serrano, D. (1998). Diferencias interhabitat en la alimentación del Buho Real (Bubo bubo) en el valle medio del Ebro (Ne de España): efecto de la disponibilidad de conejo (Oryctolagus caniculus). Ardeola, 45, 35-46.

Serrano, D. (2000). Use of farm chicken carcasses by the Eagle Owl Bubo bubo. Ardeola 47, 101103.

Taylor, I. R. (1994). Barn owls: predator-prey relationships and conservation. Cambridge, UK: Cambridge University Press.

Willgohs, J. F. (1974). The Eagle owl Bubo bubo (L.) in Norway. Part I. Food ecology. Sterna, Norsk Ornithologisk Forening og Stavanger Museum. Stavanger, 13(3), 129-177.

Yalden, D. W. (2009). The Analysis of owl pellets (4th edition). Southampton: Mammal Society. 